\title{
An Overview of COVID-19 and the Potential Plant Harboured Secondary Metabolites against SARS- CoV-2: A Review
}

\section{C.T. Swamy}

Department of Microbiology, Captain Srinivasa Murthy Central Ayurveda Research Institute, Central Council for Research in Ayurvedic Sciences, Arignar Anna Government Hospital Campus, Arumbakkam, Chennai - 600 106, Tamil Nadu, India.

\begin{abstract}
The SARS-CoV-2 virus causes COVID-19, a pandemic disease, and it is called the novel coronavirus. It belongs to the Coronaviridae family and has been plagued the world since the end of 2019. Viral infection to the lungs causes fluid filling and breathing difficulties, which leads to pneumonia. Pneumonia progresses to ARDS (Acute Respiratory Distress Syndrome), in which fluid fills the air sac and seeps from the pulmonary veins. In the current scenario, several vaccines have been used to control the pandemic worldwide. Even though vaccines are available and their effectiveness is short, it may be helpful to curb the pandemic, but long-term protection is inevitable when we look for other options. Plants have diversified components such as primary and secondary metabolites. These molecules show several activities such as anti-microbial, anti-cancer, anti-helminthic. In addition, these molecules have good binding ability to the SARS-CoV-2 virus proteins such as RdRp (RNA-dependent RNA polymerase), Mpro (Main Protease), etc. Therefore, these herbal molecules could probably be used to control the COVID-19. However, pre-requisite tests, such as cytotoxicity, in vivo, and human experimental studies, are required before plant molecules can be used as potent drugs. Plant metabolites such as alkaloids, isoquinoline ß-carboline, and quinoline alkaloids such as skimmianine, quinine, cinchonine, and dictamine are present in plants and used in a traditional medicinal system.
\end{abstract}

Keywords: COVID-19, SARS-CoV-2, Alkaloids, Flavonoids, Coumarins, Plant Secondary Metabolites, Mpro

*Correspondence: swamyct23@gmail.com

(Received: June 14, 2021; accepted: August 25, 2021)

Citation: Swamy CT. An Overview of COVID-19 and the Potential Plant Harboured Secondary Metabolites against SARS-CoV-2: A Review. J Pure Appl Microbiol. 2021; 15(3):1059-1071. doi: 10.22207/JPAM.15.3.52

(C) The Author(s) 2021. Open Access. This article is distributed under the terms of the Creative Commons Attribution 4.0 International License which permits unrestricted use, sharing, distribution, and reproduction in any medium, provided you give appropriate credit to the original author(s) and the source, provide a link to the Creative Commons license, and indicate if changes were made. 


\section{INTRODUCTION}

The emergence of new viruses and their diseases has become common in the last few decades, and this problem is a severe threat to the global population. COVID-19 was first reported in the month of December 2019 at Wuhan (China) when treating patients who showed pneumonialike symptoms. It is a pandemic that appeared after the influenza epidemic of 1918. Initially, the virus was identified as a 2019 novel coronavirus, after which name changed to acute respiratory syndrome coronavirus 2 (SARS-CoV-2) by the World Health Organization (WHO) ${ }^{1}$. COVID-19 became widespread in more than 100 countries in just 2 months. To tackle these problems, countries need a robust public health system a collective response ${ }^{2}$. On the month of March 11, 2020, the World Health Organization (WHO) declared COVID-19 as pandemic ${ }^{3}$. The COVID-19 pandemic affects depression in $25 \%$ of people, which is 7 times higher than the $3.44 \%$ in the global pool of people with global depression in $2017^{4}$.

Coronavirus belongs to the family RNA viruses, comprises a large RNA genome, i.e., positive-sense single-stranded RNA. It contains helical nucleocapsids and a huge RNA genome, and it regulates the structural and non-structural viral proteins. The entire coding sequence is essential to form a new viral particle, and some sequences are folded into a stable structure and controls the coronavirus life cycle. Subgenomic mRNAs regulate and form protein and form new virions ${ }^{5}$. The viral particle's entry and infection mainly were mediated by the ACE-2 (Angiotensin-converting enzyme 2) and TMPRSS2 (transmembrane protease serine 2) protein structures, as well as other features including binding sites and mutation points. The methylation of ACE-2 gene, DNA methylation, and post-translational histone modifications shows differences in viral infection patterns of biological age, sex-biased patterns and host tissue 6 . In addition, advanced nanotechnology products such as face masks and personal protection equipment (PPE) to specific diagnostic tools can help reduce the spread and impact of COVID-197. Remdesivir is an antiviral medication that targets the SARS-CoV-2 RdRp (RNA-dependent RNA polymerase) enzyme, which is responsible for RNA replication and is one of the virus's main therapeutic targets. The mechanism of
RdRp inhibition by nucleotide inhibitors is revealed by studying the RdRp complex (substrate RNA and Remdesivir), and it provides a molecular blueprint for developing RdRp-targeting medicines ${ }^{8}$.

Plant secondary metabolites (PSM) in plants help combat biotic stresses (microorganisms, insects, parasites) and abiotic stresses (temperature, $\mathrm{pH}$, water activity, heavy metals). In addition, these PSMs are also useful for humans, so plant and plant parts are used as nutraceuticals, drugs, and foodstuffs ${ }^{9-11}$. Plant secondary metabolites (PSMs) exhibiting antiviral activities by disturbing the viral particle constituents such as protein, lipid envelope, and genetic materials such as DNA or RNA of a virus particle. The lipid envelope of viruses is disturbed by lipophilic terpenoids of essential oils, membrane-bound viral proteins, and the viral particle's inside the host tackled by phenols and polyphenols of plants. Moreover, free virus particles are more susceptible than the virus present in the host cell to both phenolics and essential oils of plants ${ }^{12}$.

Furthermore, DNA intercalators such as berberine, $ß$-carboline, emetine, isoquinoline alkaloids, sanguinarine, and quinoline alkaloids such as cinchonine and quinine skimmianine, as well as dictamen also effectively inhibit the viral genome replication ${ }^{12}$. By blocking viral proteins and blocking virus entry into the host cell, perhaps PSMs play a key role in preventing COVID-19 from spreading. In vitro research using pomegranate peel extracts revealed an interaction between the spike glycoprotein of SARS-CoV-2 and the ACE-2 (Angiotensin-Converting Enzyme 2) receptor that prevents and inhibits the virus's $3 \mathrm{CL}$ protease activity $^{10}$.

In this present review, an overview of coronavirus, also known as COVID-19, as well as its symptoms, disease progression, infection mechanism, virus replication, control measures, treatments, and immunization were covered. The virtual drug screeing (in silico) methods including molecular docking and molecular dynamics simulation studies are also covered. Moreover, the ability of plant secondary metabolites to be active against COVID-19 in vitro and in vivo studies has also been documented.

COVID-19 Symptoms

COVID-19 exhibits various symptoms from 
mild illnesses to chronic and multi-organ failure, leading to older age patients. The most common COVID-19 symptoms include fever, cough, lung auscultation/oxygen saturation; however, this data may be used to rule out patients with COVID-19 or select for further tests. In addition, there are 27 signs and symptoms of COVID-19, which fall under 4 categories: systemic, respiratory, gastrointestinal, and cardio-vascular ${ }^{13}$. In another study, COVID-19 symptoms such as cough (50-80\%), fever ( $85 \%)$, fatigue (69.6\%), dyspnoea (20-40\%), URI (Upper Respiratory Infection) symptoms (15\%), and GI (Gastrointestinal) symptoms such as nausea, vomiting, and diarrhoea (10\%) have all been described ${ }^{14}$. However, some COVID-19 patients were complicated to diagnose because of not showing fever or radiological symptoms initially 15 . In addition, symptoms such as dyspnoea- $55 \%$ and lymphopenia-63\% were found in COVID-19 patients ${ }^{16}$.

\section{Coronavirus classification and mechanism of} cell entry

The International Committee on Virus Taxonomy states coronavirus belongs to the family Coronaviridae and the order Nidovirales. According to their phylogenetic relationships and genomic structures, the Coronavirinae subfamily is divided into Alphacoronavirus, Betacoronavirus, Gammacoronavirus and Deltacoronavirus. Both Alphacoronavirus and Betacoronavirus infect mammals. Further, birds infected by Gammacoronavirus and Deltacoronavirus, however, sometimes also infect mammals. The MERS or camel flu, SARS, and SARS-CoV-2 are Betacoronavirus members. They were further divided into the subgenera Hibecovirus, Sarbecovirus, Embecovirus Nobecovirus, and Merbecovirus $^{17-19}$.

Complete and near-complete genetic analyses of SARS-CoV-2 showed several deletions as well as mutations on coding and non-coding regions, indicating the virus's genomic variety and fast evolution ${ }^{20}$. Furthermore, a 4 per cent difference in genomic nucleotide variation was found between SARS-CoV-2 and another coronavirus related to SARS, such as bat's SARSlinked coronavirus (SARSr-CoV, RaTG13) ${ }^{21}$.

The SARS-CoV-2 spike binds to human ACE-2 (hACE2), a receptor by its RBD (receptorbinding domain), and proteolytic reactions activate proteases. Furthermore, the pseudovirus entry test revealed that RBD of SARS-CoV has lesser binding compatibility than SARS-CoV-2 RBD with hACE2. In addition, the spike of SARS-CoV-2 is shorter than the SARS-CoV, which is helpful in binding hACE2 and also useful to minimize exposure to cell defence. Furthermore, the high hACE2-binding affinity to RBD, spike's furin preactivation, and hidden RBD present in SARSCoV-2 spike are potentially helpful in evading the immune system and successful cell entry ${ }^{22}$.

Enzymes play a crucial part in the development of the disease, and they are also possible therapeutic hotspots. Four key enzymes of SARS-COV-2, such as RdRp, 3CLp, papain-like protease, helicase, and ACE-2; and transmembrane serine protease (Host factors), play an essential role in disease establishment. Interestingly, $\alpha$-glucosidase in the endoplasmic reticulum is a promising target for exploring antiSARS- CoV-2 medicines ${ }^{23}$.

\section{Variants of CoV-2}

In the United Kingdom, a novel SARSCoV-2 variety (known as 20l/501Y.V1, VOC 202012/01, or B.1.1.7) developed with many changes toward the end of December 2020. Furthermore, scientists discovered in January 2021 that variation B.1.1.7 had a greater mortality risk compared to other variants. Another potential SARS-CoV-2 (20H/501Y.V2 or B.1.351) emerged from B.1.1.7 strain in South Africa ${ }^{24}$. A thorough examination of the whole-genome sequences of 837 Indian SARS-CoV-2 strains revealed the presence of 33 distinct mutations, 18 of which were unique to India. There are $\mathrm{S}$ glycoprotein (6/33) mutation, NSP3 (5/33) mutation, RDRP / NSP12 (4/33) etc., were found ${ }^{25}$. In India, SARSCoV-2 variants such as Delta (B.1.617.2) and Kappa (B.1.617.1) were reported and become a dominant strain causing infection in a large population across more than 50 countries $^{26}$. According to outbreak information, B.1.617.2 strain has a $36 \%$ variant of concern and significant threatening strain in India ${ }^{27}$. A study revealed that SARS-CoV-2 strain B.1.617.2 reported to have hallmark mutations in receptor-binding domain (RBD) and spike protein D111D, G142D, L452R, E484Q, D614G, and P681R. The SARS-CoV-2 strains B.1.617.1 and B.1.617.2 were cause second wave in India and whole genome or next genaration sequence analysis of 
viral RNA revealed mutations at residue positions 452, 484 and 681compared with other globally circulating lineages ${ }^{28}$.

\section{Immunology of COVID-19}

Humoral and cell-mediated immunity of both types of immune responses is particularly prominent when COVID-19 infection occurs. However, cell-mediated immunity is prime and effective against viral infections ${ }^{29}$. In COVID-19 patients, abnormal lymphocyte distribution, an increase in mature natural killer cells (NK), and a decrease in T cells have been identified. NK cells overexpressed T-cell immunoglobulin, mucin-3 domain (TIM-3), and CD69, as well as CD8+ T cells, were also reported. NK cell exhaustion was identified by increased PD-1 (Programmed Cell Death Protein 1) frequencies in positive cells, NKG2D DNAM-1 frequencies were decreased [Natural Killer Group 2 D (NKG2D)-DNAX accessory molecule-1 (DNAM-1)], and Siglec-7 (sialic acidbinding Ig-like lectin 7) expressing NK cells, and interferon (IFN) secretion ability reduced. Further, interferon (IFN) $\gamma$ secretion ability also reduced observed, and serum IL-6 levels were higher in deceased patients than in survivors ${ }^{30}$. Plasma levels of interleukins 2, 7, and 10, GSCF, MIP1A, IP10, MCP1, and TNF were higher in ICU admissions patients than in non-ICU patients, indicating that the severity of the disease had increased $^{16}$.

A gradual decrease in viral load and increased antibodies have been reported in patients after one week of infection. According to the study, the viral load was highest during the first week and dropped by the second week. Furthermore, antibodies such as IgG and IgM are often detected 10 days after viral infection, and these play an essential role in neutralizing the SARS-COV-2 virus ${ }^{31,32}$.

Further, antibodies produced from coronavirus variant 501Y.V2 are also effective against the previously reported coronavirus variants. Therefore, the vaccine from the 501Y.V2 variant can be used against a variety of coronavirus strains $^{33}$.

\section{Mode of transmission of SARS-CoV-2}

The transmission of SARS-CoV-2 occurs by contact and droplet transmission, airborne transmission, fomite transmission, and other modes of transmission, such as faecal-oral contamination, blood-borne transmission, transmission from mother to child, and transmission from animals to humans ${ }^{34,35}$.

\section{COVID-19 protective measures}

According to the WHO guidelines, wash or clean the hands frequently or often, while coughing or sneezing use the bent elbow, touching of eyes, nose, and mouth with hands, avoid social gatherings and crowded places, make a suitable distance from the sick, disinfect, and clean touched objects and surfaces ${ }^{35}$. Furthermore, WHO recommendations suggest identifying suspicions early and testing them as soon as feasible and isolating sick people in appropriate facilities. As early as possible, identify and quarantine all intimate contact with infected people, and will be tested and take appropriate actions for those who show symptoms. Fabric masks are used in public areas and to provide physical separation where there is a risk of communicable disease transmission. Health workers should be taken care of not to contact and droplets formed by COVID-19 patients, and aerosol production avoided. Health workers advise continuous usage of a medical mask throughout the shift for all normal activities. Hygiene at all times, physical separation, avoidance of crowded areas, close-contact situations, and cramped and enclosed rooms with poor ventilation are all recommended ${ }^{34}$.

\section{Vaccines for COVID-19}

There are several vaccine candidates used today, and a mass vaccination program started in several countries. Vaccines such as Johnson \& Johnson's, Moderna, AstraZeneca, PfizerBioNTech, Janssen, Covaxin, Covishield, etc., are widely used in mass vaccination programs around the world. The types of vaccines used for COVID-19 are mRNA vaccines, protein subunit vaccines, and vector vaccines. It usually takes several weeks after vaccination for the organism to produce $T$ and $B$ lymphocytes. Therefore, it is possible for humans to get an infection and become sick from a virus just before or after vaccination due to didn't have time for protection. The immunization induces Macrophages, B-lymphocytes, and T-lymphocytes are responsible for immunity development ${ }^{36}$. In India, vaccines such as Covishield ${ }^{\circledR}$ and Covaxin ${ }^{\circledR}$ are permitted emergency use authorization by Central Drugs Standard Control Organization (CDSCO). Covishield comprised inactivated 
adenovirus with segments of Coronavirus, Aluminum Hydroxide Gel, L-Histidine, L-Histidine Hydrochloride Monohydrate, Magnesium Chloride Hexahydrate, Polysorbate 80, Ethanol, Sucrose, Sodium Chloride, and Disodium Edetate Dihydrate (EDTA). Further, Covaxin comprised inactivated Coronavirus, Aluminum Hydroxide Gel, TLR 7/8 Agonist, 2-Phenoxyethanol, and Phosphate Buffered Saline $[N K A 1]^{37}$. Further, there are 7 vaccines like Covaxin (Bharat Biotech), Serum Institute of India Covishield (Oxford/AstraZeneca formulation), AZD1222 (Oxford/AstraZeneca), Ad26.COV2.S Janssen (Johnson \& Johnson), Sputnik V (Gamaleya), mRNA-1273 (Moderna), and ZyCoV-D (Zydus Cadila) are approved for use in India. Moreover, in India 13 vaccines are under clinical trials ${ }^{38}$.

\section{PSMs against COVID-19}

In the evoke of the second wave of COVID-19, medicines are used for a short time so far, no particular medicine is not available for this disease, and the drug discovery process is ongoing. The plants are well-known producers of many low molecular weights based on the inferred functions classified into primary and secondary metabolites and hormones. Plant growth relies heavily on primary metabolites; hormones helpful in organism activities and metabolism; secondary metabolites play an essential role in plant-environment interactions, plant defence, etc. Interestingly, the boundary of activity of these metabolites is not fully known, so a comprehensive study on the effect of the activity of these molecules needs to be conducted ${ }^{39}$. The diverse phytochemicals such as terpenoids, organosulfur compounds, flavonoids, sulphides, limonoids, lignans, alkaloids, polyenes, polyphenolics, coumarins, saponins, thiophenes, chlorophyllins, furyl compounds, peptides, and proteins exhibit antiviral activities against a wide array of viruses ${ }^{40}$. Table 1 lists prospective phytochemicals and their inhibitory effect on SARS-CoV-2, whereas Table 2 lists medicinal plants and their prospective phytochemicals that are effective against SARSCoV-2. The protein sequences of SARS-CoV-2 3CLpro and SARS-CoV 3CLpro were 99.02 per cent identical. According to molecular docking and molecular dynamic simulation studies, about 9 active phytochemicals suggested as SARS-CoV-2 antiviral molecules based on their docking score and binding affinity ${ }^{41}$.

\section{Artificial or virtual natural drug molecules} screening methods for SARS-CoV-2

Bioactive compounds are constantly being investigated in creating novel bioactive molecules with industrial uses, gaining attention from the scientific community due to their pharmacophorelike structures, pharmacokinetic qualities, and chemical space ${ }^{42}$. Computational approaches have revolutionised the identification of novel specific bioactive compounds by evaluating vast structural libraries in silico against a bioreceptor or biological system, lowering the cost, facilities, and time to identify new compounds ${ }^{42,43}$. Machine learning-based models trained on specific proteins have provided affordable and quick-to-implement approaches for the development of successful viral treatments in the recent decade. These models can forecast inhibitor candidates in a structuralbased way given a target biomolecule ${ }^{44,45}$. Artificial intelligence (Al) uses reasoning, representation of knowledge and solution-oriented search; however, machine learning (ML) play an key role in this. $\mathrm{ML}$ is a type of machine learning that employs algorithms to detect patterns in a set of data that has been further categorised. Deep learning (DL) is a branch of machine learning that uses artificial neural networks (ANNs) which are mimicking of human neurons kind ${ }^{45,46}$. With the low cost various in silico methods helpful to analyze the virtual chemical gaps considering with ligand interaction and structure in drug discovery process. To choose a lead molecule, drug design methods such as coulomb matrices and molecular fingerprint recognition analyse the physical, chemical, and toxicological characteristics ${ }^{47,48}$. Various Al tools such as DeepChem, Deep Neural Net QSAR, DeltaVina, AlphaFold, ORGANIC etc., are using in the drug discovery method, protein folding, ligand interaction study ${ }^{45}$.

A virtual drug screening comprises mainly library preparation and suitable computational techniques. Library preparation consists of structure of compounds obtaining and convert them into readable formats like SMILES, SDF and MOL2 (simplified molecular-input line entry system, structure data file and MDL Molfile). The computational techniques includes both 
Table 1. List of Phytochemicals and their inhibitory effect against SARS-CoV-2

\begin{tabular}{|c|c|c|c|c|c|}
\hline No. & Compound & $\begin{array}{l}\text { Inhibitory } \\
\text { Concen./ } \\
\mathrm{IC}_{50} \text { or } \mathrm{LD}_{50}\end{array}$ & $\begin{array}{l}\text { Cell lines used/ Animal } \\
\text { model/Molecular } \\
\text { Docking }\end{array}$ & Standard Used & Ref. \\
\hline I & Flavonoids & & & & \\
\hline 1. & Baicalein & $\mathrm{IC}_{50}=10 \mu \mathrm{M}$ & $\begin{array}{l}\text { SARS-CoV-2 in Vero } \\
\text { E6 cells. }\end{array}$ & Staurosporine & 75 \\
\hline 2. & Baicalin & $\begin{array}{l}\mathrm{IC}_{50}=0.39 \mu \mathrm{M} \\
\text { (SARS-CoV- } \\
23 \mathrm{CLpro})\end{array}$ & $\begin{array}{l}\text { SARS-CoV-2 in Vero } \\
\text { E6 cells. }\end{array}$ & Remdesivir & 76 \\
\hline 3. & Scutellarin & $\begin{array}{l}\mathrm{IC}_{50}=5.8 \mu \mathrm{M} \text { (SARS- } \\
\text { CoV-2 3CLpro) }\end{array}$ & $\begin{array}{l}\text { Molecular Docking } \\
\text { study }\end{array}$ & $\begin{array}{l}\text { baicalein analogue flavonoids } \\
\text { (baicalein) }\end{array}$ & 77 \\
\hline 4. & Quercetin & $\mathrm{LD}_{50}=159 \mathrm{mg} / \mathrm{kg}$ & $\begin{array}{l}\text { Molecular Docking } \\
\text { study }\end{array}$ & $\begin{array}{l}\text { Hydroxychloroquine Chloroquine } \\
\text { and methyl 4-sulfamoylbenzoate }\end{array}$ & 78 \\
\hline 5. & Naringin & $\mathrm{LD}_{50}=2300 \mathrm{mg} / \mathrm{kg}$ & $\begin{array}{l}\text { Molecular Docking } \\
\text { study }\end{array}$ & $\begin{array}{l}\text { Hydroxychloroquine Chloroquine } \\
\text { and methyl 4-sulfamoylbenzoate }\end{array}$ & 78 \\
\hline 6. & Catechin & $\begin{array}{l}\mathrm{LD}_{50}=10,000 \\
\mathrm{mg} / \mathrm{kg}\end{array}$ & $\begin{array}{l}\text { Molecular Docking } \\
\text { study }\end{array}$ & $\begin{array}{l}\text { Hydroxychloroquine Chloroquine } \\
\text { and methyl 4-sulfamoylbenzoate }\end{array}$ & 78 \\
\hline II & Phenols & & & & \\
\hline 1. & Oleuropein & $\begin{array}{l}\text { Mpro and 3CLpro } \\
\text { protease }\end{array}$ & $\begin{array}{l}\text { Molecular Docking } \\
\text { study }\end{array}$ & $\begin{array}{l}\text { Hydroxychloroquine Chloroquine } \\
\text { and methyl 4-sulfamoylbenzoate }\end{array}$ & 78 \\
\hline 2. & $\begin{array}{l}\text { Hydroxyty- } \\
\text { rosol }\end{array}$ & $\begin{array}{l}\text { Mpro and 3CLpro } \\
\text { protease }\end{array}$ & $\begin{array}{l}\text { Molecular Docking } \\
\text { study }\end{array}$ & $\begin{array}{l}\text { Hydroxychloroquine Chloroquine } \\
\text { and methyl 4-sulfamoylbenzoate }\end{array}$ & 78 \\
\hline 3. & Gallic acid & $\mathrm{LD}_{50}=2260 \mathrm{mg} / \mathrm{kg}$ & $\begin{array}{l}\text { Molecular Docking } \\
\text { study }\end{array}$ & $\begin{array}{l}\text { Hydroxychloroquine Chloroquine } \\
\text { and methyl 4-sulfamoylbenzoate }\end{array}$ & 78 \\
\hline 4. & Psychotrine & $\mathrm{LD}_{50}=480 \mathrm{mg} / \mathrm{kg}$ & $\begin{array}{l}\text { Molecular Docking } \\
\text { study }\end{array}$ & $\begin{array}{l}\text { Hydroxychloroquine Chloroquine } \\
\text { and methyl 4-sulfamoylbenzoate }\end{array}$ & 78 \\
\hline 5. & Curcumin & $\mathrm{LD}_{50}=4000 \mathrm{mg} / \mathrm{kg}$ & $\begin{array}{l}\text { Molecular Docking } \\
\text { study }\end{array}$ & $\begin{array}{l}\text { Hydroxychloroquine Chloroquine } \\
\text { and methyl 4-sulfamoylbenzoate }\end{array}$ & 78 \\
\hline III & Terpenoids & & & & \\
\hline 1. & Asiatic acid & $\mathrm{IC}_{50}=9 \mu \mathrm{M}$ & HIV-1; EV-7 & - & 79 \\
\hline 2. & $\beta$-Aescin & $\mathrm{IC}_{50}=6 \mu \mathrm{M}$ & For SARS-CoV-1 & - & 79 \\
\hline 3. & Maslinic & $\mathrm{IC}_{50}^{50}=9 \mu \mathrm{M}$ & HIV-1 & - & 79 \\
\hline 4. & Ursolic acid & $\mathrm{IC}_{50}=10 \mu \mathrm{M}$ & HIV-1 & - & 79 \\
\hline 5. & Pachymic acid & $\begin{array}{l}\mathrm{IC}_{50}=18.607 \\
\mu \mathrm{mol} \mathrm{L}\end{array}$ & $\begin{array}{l}\text { SARS-CoV- } 2 \text { main } \\
\text { protease }\left(\mathrm{M}^{\text {pro }}\right)\end{array}$ & Standard Pachymic acid & 80 \\
\hline IV & Saponins & & & & \\
\hline 1. & Ellagic acid & $\begin{array}{l}-8.4 \mathrm{kcal} / \mathrm{mol} \\
\text { (Dock score) }\end{array}$ & $\begin{array}{l}\text { SARS-CoV- } 2 \text { main } \\
\text { protease }\left(\mathrm{M}^{\text {pro }}\right)\end{array}$ & $\begin{array}{l}\text { Remdesivir, Dexamethasone, } \\
\text { N3Inhibitor }\end{array}$ & 65 \\
\hline 2. & $\begin{array}{l}\text { Arjunic acid } \\
(-8.1 \mathrm{kcal} / \mathrm{mol})\end{array}$ & $\begin{array}{l}-8.1 \mathrm{kcal} / \mathrm{mol} \\
\text { (Dock score) }\end{array}$ & $\begin{array}{l}\text { SARS-CoV- } 2 \text { main } \\
\text { protease }\left(\mathrm{M}^{\text {pro }}\right)\end{array}$ & $\begin{array}{l}\text { Remdesivir, Dexamethasone, } \\
\text { N3Inhibitor }\end{array}$ & 65 \\
\hline 3. & $\begin{array}{l}\text { Theasapogenol } \\
\text { B }\end{array}$ & $\begin{array}{l}-8.1 \mathrm{kcal} / \mathrm{mol} \\
\text { (Dock score) }\end{array}$ & $\begin{array}{l}\text { SARS-CoV- } 2 \text { main } \\
\text { protease }\left(\mathrm{M}^{\text {pro }}\right)\end{array}$ & $\begin{array}{l}\text { Remdesivir, Dexamethasone, } \\
\text { N3Inhibitor }\end{array}$ & 65 \\
\hline 4. & Euscaphic Acid & $\begin{array}{l}-8.0 \mathrm{kcal} / \mathrm{mol} \\
\text { (Dock score) }\end{array}$ & $\begin{array}{l}\text { SARS-CoV- } 2 \text { main } \\
\text { protease }\left(\mathrm{M}^{\text {pro }}\right)\end{array}$ & $\begin{array}{l}\text { Remdesivir, Dexamethasone, } \\
\text { N3Inhibitor }\end{array}$ & 65 \\
\hline V & Alkaloids & & & & \\
\hline 1. & Anisotine & $\begin{array}{l}-7.9 \mathrm{kcal} / \mathrm{mol} \\
\text { (Dock score) }\end{array}$ & $\begin{array}{l}\text { SARS-CoV- } 2 \text { main } \\
\text { protease }\left(\mathrm{M}^{\text {pro }}\right)\end{array}$ & Lopinavir and Darunavir & 81 \\
\hline 2. & Berberine & $\mathrm{EC}_{50}=9.1 \mu \mathrm{M}$ & $\begin{array}{l}\text { SARS-CoV-2 in Vero } \\
\text { E6 cells. }\end{array}$ & $0.1 \%$ DMSO as negative control & 68 \\
\hline 3. & Obatoclax & $\mathrm{EC}_{50}=67 \mathrm{nM}$ & $\begin{array}{l}\text { SARS-CoV-2 in Vero } \\
\text { E6 cells. }\end{array}$ & $0.1 \%$ DMSO as negative control & 68 \\
\hline
\end{tabular}


Table 2. List of Plants and their Phytochemicals effective against SARS-CoV-2

\begin{tabular}{|c|c|c|c|c|}
\hline No. & Plant & Compound & Standard Used & Ref. \\
\hline 1. & $\begin{array}{l}\text { Psorothamnus } \\
\text { arborescens }\end{array}$ & $\begin{array}{l}5,7,3^{\prime}, 4^{\prime}-\text { Tetrahydroxy-2'-(3,3- } \\
\text { dimethylallyl) isoflavone }\end{array}$ & $\begin{array}{l}\text { Nelfinavir, Prulifloxacin and } \\
\text { Colistin }\end{array}$ & 41 \\
\hline 2. & Myrica cerifera & Myricitrin & $\begin{array}{l}\text { Nelfinavir, Prulifloxacin and } \\
\text { Colistin }\end{array}$ & 41 \\
\hline 3. & $\begin{array}{l}\text { Hyptis atrorubens } \\
\text { Poit }\end{array}$ & Methyl rosmarinate & $\begin{array}{l}\text { Nelfinavir, Prulifloxacin and } \\
\text { Colistin }\end{array}$ & 41 \\
\hline 4. & Phaseolus vulgaris & $\begin{array}{l}3,5,7,3^{\prime}, 4^{\prime}, 5^{\prime} \text {-hexahydroxy } \\
\text { flavanone-3-O-beta-D- } \\
\text { glucopyranoside }\end{array}$ & $\begin{array}{l}\text { Nelfinavir, Prulifloxacin and } \\
\text { Colistin }\end{array}$ & 41 \\
\hline 5. & Phyllanthus emblica & $\begin{array}{l}\text { (2S)-Eriodictyol 7-O-(6"- } \\
\text { O-galloyl)-beta-D- } \\
\text { glucopyranoside }\end{array}$ & $\begin{array}{l}\text { Nelfinavir, Prulifloxacin and } \\
\text { Colistin }\end{array}$ & 41 \\
\hline 6. & Fraxinus sieboldiana & Calceolarioside B & $\begin{array}{l}\text { Nelfinavir, Prulifloxacin and } \\
\text { Colistin }\end{array}$ & 41 \\
\hline 7. & Camellia sinensis & $\begin{array}{l}\text { Myricetin 3-O-beta-D- } \\
\text { glucopyranoside }\end{array}$ & $\begin{array}{l}\text { Nelfinavir, Prulifloxacin and } \\
\text { Colistin }\end{array}$ & 41 \\
\hline 8. & Glycyrrhiza uralensis & Licoleafol & $\begin{array}{l}\text { Nelfinavir, Prulifloxacin and } \\
\text { Colistin }\end{array}$ & 41 \\
\hline 9. & Amaranthus tricolor & Amaranthin & $\begin{array}{l}\text { Nelfinavir, Prulifloxacin and } \\
\text { Colistin }\end{array}$ & 41 \\
\hline 10. & $\begin{array}{l}\text { Anemarrhenae } \\
\text { Rhizoma }\end{array}$ & 3 Antiviral compounds & - & 82 \\
\hline 11. & Anisi Stellati Fructus & 3 Antiviral compounds & - & 82 \\
\hline 12. & Carthami Flos & 3 Antiviral compounds & - & 82 \\
\hline 13. & Daturae Flos & 3 Antiviral compounds & - & 82 \\
\hline 14. & Black Tea & Theaflavin & - & 83 \\
\hline 15. & Echinacea purpurea & Several active compounds & & 55,56 \\
\hline 16. & Olea europaea & $\begin{array}{l}\text { phenols (oleuropein and } \\
\text { hydroxytyrosol) and terpenoids } \\
\text { (oleanolic, maslinic and ursolic } \\
\text { acid). }\end{array}$ & - & 84 \\
\hline 17. & Scutellaria baicalensis & Scutellarin & $\begin{array}{l}\text { baicalein analogue flavonoids } \\
\text { (baicalein) }\end{array}$ & 77 \\
\hline 18. & Ampelopsis japonica & Dihydromyricetin, & $\begin{array}{l}\text { baicalein analogue flavonoids } \\
\text { (baicalein) }\end{array}$ & 77 \\
\hline 19. & $\begin{array}{l}\text { Eriocaulon } \\
\text { buergerianum }\end{array}$ & Quercetagetin & $\begin{array}{l}\text { baicalein analogue flavonoids } \\
\text { (baicalein) }\end{array}$ & 77 \\
\hline 20. & Polygoni avicularis & Myricetin & $\begin{array}{l}\text { baicalein analogue flavonoids } \\
\text { (baicalein) }\end{array}$ & 77 \\
\hline 21. & Poria cocos & Pachymic acid & Standard Pachymic acid & 80 \\
\hline 22. & $\begin{array}{l}\text { Boerhavia diffusa } \\
\text { Linn. }\end{array}$ & $\begin{array}{l}\text { Biorobin, Bioquercetin, } \\
\text { Boerhavisterol, kaempferol, } \\
\text { Boeravinone J, Quercetin, } \\
\text { Liriodendrin, Trans - caftaric } \\
\text { acid, 2-3-4 beta-Ecdysone }\end{array}$ & - & 85 \\
\hline
\end{tabular}


SBVS- structure-based virtual screening or LBVSligand based virtual screening. After the library prepartion, computational techniques employed and finally in silico results validating by in vitro and in vivo assays ${ }^{42}$. The majority of machine learning drug discovery studies of SARS-CoV-2 focused on viral protiens such as spike (S) protein, MPro, 3CLPro etc., protein ligand interaction, binding effeciency, and binding free energy are also considered in the process $s^{44,49,50}$. The studies on SARS-CoV-2 drug discovery focused on the sequence of target proteins such as 3 CLPro, $S$ protein, ACE-2, Main Protease, RdRP and host TMPRSS2 protease ACE2 receptor are considered. Later by adapting the deep docking, QSAR etc., are using to identify the protein inhibitors from available databases like FDA approved drugs, ZINC database etc. In majority of studies 3CLPro of SARS-CoV-2 is target protein, Deep learning model and molecular dynamic simulation methods approched to finilise the highest hit compound to target protein like 3CLPro of SARS-CoV-2 $2^{42,44,49-53}$.

Some of the extracts of litchi seeds, Houttuynia cordata, Chinese Rhubarb extracts, Isatis indigotica plants (beta-sistosterol) root extract can inhibit the SARS enzymatic activity ${ }^{54}$. In addition, immune-modulating supplements such as Echinacea purpurea consumption may prevent the infection ${ }^{55,56}$. Around 219 plants from 83 families showed antiviral activity and screened the major plant secondary metabolites (PSMs) from 149 plants of 71 families for the COVID-19 pandemic ${ }^{57}$. The computer simulation (in silico) studies come out with phytochemicals such as glycyrrhizic acid, 7-deacetyl-7- benzoylgedunin, limonin, maslinic acid, obacunone, corosolic acid, and ursolic acid are effective against some proteins of SARS-CoV-2. These studies majorly focused on viral proteins such as PLpro, SpG-RBD, 3CLpro, RdRp, and ACE- $2^{58}$.

Plants ubiquitously have a diversified flavonoid known as natural health products and chemically showed a 15-carbon skeleton of C6C3-C6 with different subclasses based on structural configuration. The major subclasses of flavonoids are flavanols or catechins, flavones, flavonols, flavanones, anthocyanins, and isoflavones ${ }^{59}$.

Flavonoids could be efficacious as antiviral chemicals that have an essential function in modulating signalling pathways, which is critical for COVID-19 survival, especially on inflammation and immunity. Some flavonoids also inhibit essential proteins such as PLpro (papain-like protease), 3CLpro (3C-like protease), NTPase/helicase, which was instrumental in the formation of COVID-196. In addition, modulation of the immune system by flavonoids through inflammatory intermediaries like endothelial activation inhibition, NOD-, LRR-, and pyrin domain-containing 3 (NLRP3) inflammasome, toll-like receptors (TLRs) or BRD4, and Nrf2 (nuclear factor erythroid-derived 2-related factor 2) activation are helpful to cytokine regulation for COVID-19 infection. Furthermore, flavonoids inhibit DPP4, neutralize 3CLpro (3-chymotrypsinlike protease) and ACE-2 (angiotensin-converting enzyme 2) in SARS-COV- ${ }^{61}$.

Triterpenoids are large group of phytochemicals, which are metabolites of isopentenyl pyrophosphate oligomers ${ }^{62}$. Triterpenoids are naturally found in Oleanolic, betulinic, and ursolic acid forms, and they exhibit a broad spectrum of antiviral, antitumor, and antiinflammatory activities ${ }^{63}$.

In a study, among selected plant secondary metabolites, superior molecule triterpenoids exhibited lower binding energy ( $>50 \%$ ) and firmly interacted with the viral receptor-binding domain of spike protein. Further, flavonoids and glycosides exhibited $>32 \%$ of interaction with the human transmembrane serine protease active site. The lower binding energy was exhibited by flavonol glycosides and anthocyanidins with $>16 \%$ of the viral main protease active site. Interestingly, the glycoside of flavonol interacts very firmly with viral RNA-dependent RNA polymerase $(>13 \%)$. Some Triterpenoid plant secondary metabolites, including Coagulins, Withanolides, Pseudojervine, and others, can actively inhibit the AARs of spike protein, which interacts with hACE2, blocking host cell detection by SARS -CoV- ${ }^{64}$.

Saponins are the glycosides of triterpenes and steroids that occur naturally in non-volatile and surface-active glycosides and exhibit various pharmacological activities. Saponins have antiviral action and perhaps be used as vaccine adjuvants in mammals because of their capacity to stimulate and activate the immune system ${ }^{65}$.

Alkaloids are significant plant secondary metabolites with a nitrogen atom or elements 
like amino or amido groups in their structure, which results in alkalinity. Alkaloids are cyclic structure ones based on a structure divided into isoquinolines, pyrrolizidines, quinolines, pyridines, isoquinolines, pyrrolidinestropanes, indoles, and terpenoids and steroids ${ }^{66}$.

Alkaloids from medicinal plants of Africa may interrupt cell entry of SARS virus by attaching with spike glycoprotein, human cell receptor ACE-2 blocking and inhibiting the host cell serine protease TMPRSS2 ${ }^{67}$. The in vitro study of alkaloids such as Berberine and Obatoclax effectively inhibited replication of SARS-Cov- 2 in human nasal epithelial cells. However, efficacy tests are required for further usage as potential antivirals. It is interesting to note that Obatoclax showed its effectiveness at early steps in the life cycle of a virus, such as entry processes. On the other hand, berberine was more active in the later phases of the viral life cycle, suggesting that it may limit the infectivity of newly generated virions ${ }^{68}$.

A polyphenolic colourless crystalline oxygenated heterocyclic compound is called Coumarins. Coumarins are naturally found in free forms, and their 800 derivatives are reported from 600 genera of several plants' families ${ }^{69}$. Coumarins used as therapeutic agents and a molecular docking study showed that coumarin analogues such as toddacoumaquinone and synthesized coumarin analogue $(1 \mathrm{~m})$ had $7.8 \mathrm{kcal} /$ $\mathrm{mol}$ to be the binding energy and $-7.1 \mathrm{kcal} / \mathrm{mol}$, respectively ${ }^{70}$.

Methyltransferase (MTase), Endoribonuclease (endoU), and ADP ribose Phosphatase are required for the survivability of SARS-CoV-2 Main Protease enzymes (Mpro). Coumarins showed inhibits these proteins and exhibited antiviral activity, i.e., showed in in silico studies, -9.00 to $-7.97,-8.42$ to -6.80 , -8.63 to -7.48 and -7.30 to $-6.01 \mathrm{kcal} / \mathrm{mol}$, of docking score recorded against Methyltransferase, Endoribonuclease, and Main Protease components of virus ${ }^{71}$.

Food ingredients and other active products

Food is a vital component of life. Meanwhile, it supports the organism free from infection by improving or boosting their immunity. In addition, lipids, which are found in foods, are essential in the virus's suppression. Unsaturated fatty acids like arachidonic acid (AA), icosapentinoic acid (EPA), and docosahexaenoic acid (DHA) help reduce the inflammation, in addition to this promote wound healing, enhance macrophage and another immune cell phagocytosis, and reduce microbial load, may these activities affect the virus and acts as antiviral molecules. Perhaps after validation, oral or intravenous administration of these will increase the resistance and recovery from SARS-CoV- $2^{72}$.

Nutraceuticals include Ferulic acid, Lipoic acid, Spirulina, N-Acetylcysteine, Selenium, Glucosamine, Yeast Beta-Glucan, Zinc, Elderberry recommended to control coronavirus and influenza. For instance, these enhance the response of type 1 interferon to RNA viruses ${ }^{73}$. In addition, the docking studies revealed that Phycocyanobilin, Riboflavin, Cyanidin, Daidzein, Genistein are bioactive components of food that potentially inhibit Mpro and RdRp in the SARSCoV-2 virus ${ }^{74}$.

\section{CONCLUSION}

The plant extracts showed inhibitory action against pathogens. Bio-active components such as primary and secondary metabolites play an essential role in viral inhibition. The structure of these molecules may interrupt the attachment to the host, entry of virus particle, arrest the virus replication mechanism, interact with their genome and inhibit the disease establishment. Herbal medicine is an ancient medicine technique that exists from human existence, and nature provides many valuable molecules to human beings through plants. Plants and their products are used as food, and some are used as medicinal plants; these possess secondary metabolites protecting human beings from several diseases by improving immunity. Several plant-based components showed excellent binding capacity toward SARSCOV-2 virus proteins such as Mpro and other proteins compared with standard synthetic drugs used today. Therefore, still effective medication comes to COVID-19, the herbal-based components are a golden token to control the disease. However, the proper validation with thorough in vitro, in vivo and clinical trials of plant compounds is essential to confer before use as a drug.

\section{ACKNOWLEDGMENTS}

I would like to thank Central Council 
for Research in Ayurvedic Sciences (CCRAS) New Delhi, as well as Captain Srinivasa Murthy Central Ayurveda research Institute (CSMCARI) Chennai.

\section{FUNDING}

None.

\section{DATA AVAILABILITY}

All datasets generated or analyzed during this study are included in the manuscript.

\section{ETHICS STATEMENT}

Not applicable.

\section{REFERENCES}

1. Ramphul K, Mejias SG. Coronavirus Disease: A Review of a New Threat to Public Health. Cureus. 2020;12(3):e7276. doi: 10.7759/cureus.7276

2. De Ceukelaire W, Bodini C. We Need Strong Public Health Care to Contain the Global Corona Pandemic. Int J Health Serv. 2020;50(3):276-277. doi: 10.1177/0020731420916725

3. WHO. https://www.who.int/director-general/ speeches/detail/who-director-general-s-openingremarks-at-the-media-briefing-on-covid-19---11march-2020. Accessed Date: April 17, 2021.

4. Bueno-Notivol J, Gracia-Garcia P, Olaya B, Lasheras I, Lopez-Anton R, Santabarbara J. Prevalence of depression during the COVID-19 outbreak: A metaanalysis of community-based studies. Int J Clin Health Psychol. 2021;21(1):100196. doi: 10.1016/j. ijchp.2020.07.007

5. Manfredonia I, Incarnato D. Structure and regulation of coronavirus genomes: state-of-the-art and novel insights from SARS-CoV-2 studies. Biochem Soc Trans. 2021;49(1):341-352. doi: 10.1042/BST20200670

6. Chlamydas S, Papavassiliou AG, Piperi C. Epigenetic mechanisms regulating COVID-19 infection. Epigenetics. 2021;16(3):263-270. doi: 10.1080/15592294.2020.1796896

7. Tharayil A, Rajakumari R, Chirayil CJ, Thomas S, Kalarikkal N. A short review on nanotechnology interventions against COVID-19. Emergent Mater. 2021;4(1):131-141. doi: 10.1007/s42247-021-00163-z

8. Jiang Y, Yin W, Xu HE. RNA-dependent RNA polymerase: Structure, mechanism, and drug discovery for COVID-19. Biochem Biophys Res Commun. 2021;538:47-53. doi: 10.1016/j.bbrc.2020.08.116

9. Yang L, Wen K-S, Ruan X, Zhao Y-X, Wei F, Wang Q. Response of Plant Secondary Metabolites to Environmental Factors. Molecules. 2018;23(4):762. doi: 10.3390/molecules23040762

10. Isah T. Stress and defense responses in plant secondary metabolites production. Biol Res. 2019;52(1):39. doi: 10.1186/s40659-019-0246-3

11. Tito A, Colantuono A, Pirone L, et al. Pomegranate Peel Extract as an Inhibitor of SARS-CoV-2 Spike Binding to Human ACE2 Receptor (in vitro): A Promising Source of Novel Antiviral Drugs. Front Chem. 2021;9:638187. doi: 10.3389/fchem.2021.638187

12. Wink M. Potential of DNA Intercalating Alkaloids and Other Plant Secondary Metabolites against SARS-CoV-2 Causing COVID-19. Diversity. 2020;12(5):175. doi: 10.3390/d12050175

13. Struyf T, Deeks JJ, Dinnes J, et al. Signs and symptoms to determine if a patient presenting in primary care or hospital outpatient settings has COVID-19 disease. Cochrane Database Syst Rev. 2020;7:CD013665. doi: 10.1002/14651858.CD013665

14. Jamil S, Mark N, Carlos G, Cruz CS D, Gross JE, Pasnick S. Diagnosis and Management of COVID-19 Disease. Am J Respir Crit Care Med. 2020;201(10):P19-P20. doi: 10.1164/rccm.2020C1

15. Guan W, Ni Z, Hu Y, et al. Clinical Characteristics of Coronavirus Disease 2019 in China. N Engl J Med. 2020;382(18):1708-1720. doi: 10.1056/ NEJMoa2002032

16. Huang $\mathrm{C}$, Wang $\mathrm{Y}$, Li $\mathrm{X}$, et al. Clinical features of patients infected with 2019 novel coronavirus in Wuhan, China. Lancet. 2020;395(10223):497-506. doi: 10.1016/ S0140-6736(20)30183-5

17. Woo PCY, Lau SKP, Lam CSF, et al. Discovery of Seven Novel Mammalian and Avian Coronaviruses in the Genus Deltacoronavirus Supports Bat Coronaviruses as the Gene Source of Alphacoronavirus and Betacoronavirus and Avian Coronaviruses as the Gene Source of Gammacoronavirus and Deltacoronavi. J Virol. 2012;86(7):3995-4008. doi: 10.1128/JVI.0654011

18. Cui J, Li F, Shi Z-L. Origin and evolution of pathogenic coronaviruses. Nat Rev Microbiol. 2019;17(3):181-192. doi: 10.1038/s41579-018-0118-9

19. Wassenaar TM, Zou Y. 2019_nCoV/SARS-CoV-2: rapid classification of betacoronaviruses and identification of Traditional Chinese Medicine as potential origin of zoonotic coronaviruses. Lett Appl Microbiol. 2020;70(5):342-348. doi: 10.1111/lam.13285

20. Phan T. Genetic diversity and evolution of SARS-CoV-2. Infect Genet Evol. 2020;81:104260. doi: 10.1016/j. meegid.2020.104260

21. Tang X, Wu C, Li X, et al. On the origin and continuing evolution of SARS-CoV-2. Nat/ Sci Rev. 2020;7(6):10121023. doi: $10.1093 / \mathrm{nsr} / \mathrm{nwaa036}$

22. Shang J, Wan Y, Luo C, et al. Cell entry mechanisms of SARS-CoV-2. Proc Natl Acad Sci. 2020;117(21):1172711734. doi: 10.1073/pnas.2003138117

23. Shahid M, Shahzad-ul-Hussan S. Structural insights of key enzymes into therapeutic intervention against SARS-CoV-2. J Struct Biol. 2021;213(1):107690. doi: 10.1016/j.jsb.2020.107690

24. $\operatorname{CDC}(\mathrm{a})$. Science Brief: Emerging SARS-CoV-2 Variants, 01 2021. Published 2021. https://www.cdc.gov/ coronavirus/2019-ncov/science/science-briefs/ scientific-brief-emerging-variants.html. Accessed April 17, 2021.

25. Sarkar R, Mitra S, Chandra P, et al. Comprehensive analysis of genomic diversity of SARS-CoV-2 in different geographic regions of India: an endeavour to classify Indian SARS-CoV-2 strains on the basis of co-existing mutations. Arch Virol. 2021;166(3):801-812. doi: 


\subsection{7/s00705-020-04911-0}

26. Farinholt T, Doddapaneni $\mathrm{H}$, Qin X, et al. Transmission event of SARS-CoV-2 Delta variant reveals multiple vaccine breakthrough infections. medRxiv Prepr Serv Heal Sci. 2021. doi: 10.1101/2021.06.28.21258780

27. Latif AA, Mullen JL, Alkuzweny M, et al. The Center for Viral Systems Biology. India Mutation Report. https:// outbreak.info/location-reports?loc=IND\&dark=true \& selected=B.1.1.7 Accessed August 21, 2021.

28. Cherian S, Potdar V, Jadhav S, et al. SARS-CoV-2 Spike Mutations, L452R, T478K, E484Q and P681R, in the Second Wave of COVID-19 in Maharashtra, India. Microorganisms. 2021;9(7):1542. doi: 10.3390/ microorganisms 9071542

29. Velikova TV, Kotsev SV, Georgiev DS, Batselova HM. Immunological aspects of COVID-19: What do we know? World J Biol Chem. 2020;11(2):14-29. doi: 10.4331/wjbc.v11.i2.14

30. Varchetta $S$, Mele D, Oliviero B, et al. Unique immunological profile in patients with COVID-19. Cell Mol Immunol. 2021;18(3):604-612. doi: 10.1038/ s41423-020-00557-9

31. To KK-W, Tsang OT-Y, Leung W-S, et al. Temporal profiles of viral load in posterior oropharyngeal saliva samples and serum antibody responses during infection by SARS-CoV-2: an observational cohort study. Lancet Infect Dis. 2020;20(5):565-574. doi: 10.1016/S14733099(20)30196-1

32. Chen Y, Li L. SARS-CoV-2: virus dynamics and host response. Lancet Infect Dis. 2020;20(5):515-516. doi: 10.1016/S1473-3099(20)30235-8

33. Cele S, Gazy I, Jackson L, et al. Escape of SARS-CoV-2 501Y.V2 from neutralization by convalescent plasma. Nature. 2021;593(7857):142-146. doi: 10.1038/ s41586-021-03471-w

34. WHO. Transmission of SARS-CoV-2: implications for infection prevention precautions. 2020. https:// www.who.int/news-room/commentaries/detail/ transmission-of-sars-cov-2-implications- for-infectionprevention-precautions. Accessed April 17, 2021.

35. WHO. Information for the public: COVID-19 transmission and protective measures. 2021. https:// www.who.int/westernpacific/emergencies/covid-19/ information/transmission-protective- measures. Accessed April 17, 2021.

36. $\mathrm{CDC}(\mathrm{b})$. Understanding How COVID-19 Vaccines Work. 2021. https://www.cdc.gov/coronavirus/2019-ncov/ vaccines/different-vaccines/how-they-work.html. Accessed April 17, 2021.

37. Ministry of Health and Family Welfare G. Frequently Asked Questions: About the Vaccine. 2021. https:// www.mohfw.gov.in/covid_vaccination/vaccination/ faqs. html\#about-the-vaccine. Accessed April 17, 2021.

38. Team MCVT. COVID 19 Vaccine Tracker. 2021. https:// covid19.trackvaccines.org/country/india/. Accessed August 21, 2021.

39. Erb M, Kliebenstein DJ. Plant Secondary Metabolites as Defenses, Regulators, and Primary Metabolites: The Blurred Functional Trichotomy. Plant Physiol. 2020;184(1):39-52. doi: 10.1104/pp.20.00433

40. Naithani R, Huma L, Holland L, et al. Antiviral Activity of Phytochemicals: A Comprehensive Review. Mini-
Reviews Med Chem. 2008;8(11):1106-1133. doi: 10.2174/138955708785909943

41. Tahir Ul Qamar M, Alqahtani SM, Alamri MA, Chen L-L. Structural basis of SARS-CoV-2 3CLpro and antiCOVID-19 drug discovery from medicinal plants. $J$ Pharm Anal. 2020;10(4):313-319. doi: 10.1016/j. jpha.2020.03.009

42. Santana K, do Nascimento LD, Lima e Lima A, et al. Applications of Virtual Screening in Bioprospecting: Facts, Shifts, and Perspectives to Explore the ChemoStructural Diversity of Natural Products. Front Chem. 2021;9:662688. doi: $10.3389 /$ fchem. 2021.662688

43. Macalino SJY, Gosu V, Hong S, Choi S. Role of computeraided drug design in modern drug discovery. Arch Pharm Res. 2015;38(9):1686-1701. doi: 10.1007/ s12272-015-0640-5

44. Keshavarzi Arshadi A, Webb J, Salem M, et al. Artificial Intelligence for COVID-19 Drug Discovery and Vaccine Development. Front Artif Intell. 2020;3:65. doi: 10.3389/frai.2020.00065

45. Paul D, Sanap G, Shenoy S, Kalyane D, Kalia K, Tekade RK. Artificial intelligence in drug discovery and development. Drug Discov Today. 2021;26(1):80-93. doi: 10.1016/j.drudis.2020.10.010

46. Beneke $\mathrm{F}$, Mackenrodt M-O. Artificial Intelligence and Collusion. IIC - Int Rev Intellect Prop Compet Law. 2019;50(1):109-134. doi: 10.1007/s40319-01800773-x

47. Mak K-K, Pichika MR. Artificial intelligence in drug development: present status and future prospects. Drug Discov Today. 2019;24(3):773-780. doi: 10.1016/j. drudis.2018.11.014

48. Chan HCS, Shan H, Dahoun T, Vogel H, Yuan S. Advancing Drug Discovery via Artificial Intelligence. Trends Pharmacol Sci. 2019;40(8):592-604. doi: 10.1016/j.tips.2019.06.004

49. Nand M, Maiti P, Joshi T, et al. Virtual screening of anti-HIV1 compounds against SARS-CoV-2: machine learning modeling, chemoinformatics and molecular dynamics simulation based analysis. Sci Rep. 2020;10(1):20397. doi: 10.1038/s41598-020-77524-x

50. Kumari M, Subbarao N. Deep learning model for virtual screening of novel 3C-like protease enzyme inhibitors against SARS coronavirus diseases. Comput Biol Med. 2021;132:104317. doi: 10.1016/j. compbiomed.2021.104317

51. Batra R, Chan H, Kamath G, Ramprasad R, Cherukara MJ, Sankaranarayanan SKRS. Screening of Therapeutic Agents for COVID-19 Using Machine Learning and Ensemble Docking Studies. J Phys Chem Lett. 2020;11(17):7058-7065. doi: 10.1021/acs. jpclett.0c02278

52. Janairo GIB, Yu DEC, Janairo JIB. A machine learning regression model for the screening and design of potential SARS-CoV-2 protease inhibitors. Netw Model Anal Heal informatics Bioinforma. 2021;10(1):51. doi: 10.1007/s13721-021-00326-2

53. Parikesit AA, Ratnasari NRP, Anurogo D. Application of Artificial Intelligence-Based Computation in the Health Sciences to Ward off the COVID-19 Pandemic. Int J Hum Heal Sci. 2021;5(2):177-184. doi: 10.31344/ ijhhs.v5i2.256 
54. Singh YD, Jena B, Ningthoujam R, et al. Potential bioactive molecules from natural products to combat against coronavirus. Adv Tradit Med. 2020. doi: 10.1007/s13596-020-00496-w

55. Aucoin M, Cooley K, Saunders PR, et al. The effect of Echinacea spp. on the prevention or treatment of COVID-19 and other respiratory tract infections in humans: A rapid review. Adv Integr Med. 2020;7(4):203-217. doi: 10.1016/j.aimed.2020.07.004

56. Kembuan GJ, Lie W, Tumimomor AH. Potential usage of immune modulating supplements of the Echinacea genus for COVID-19 infection. Int J Med Rev Case Reports. 2020;4(9):13-17. doi:10.5455/IJMRCR. immune-modulating-supplements-Echinacea-genuscovid-19-infection

57. Khan T, Khan MA, Karam K, Ullah N, Mashwani Z-R, Nadhman A. Plant in vitro Culture Technologies; A Promise Into Factories of Secondary Metabolites Against COVID-19. Front Plant Sci. 2021;12:610194. doi: 10.3389/fpls.2021.610194

58. Vardhan S, Sahoo SK. In silico ADMET and molecular docking study on searching potential inhibitors from limonoids and triterpenoids for COVID-19. Comput Biol Med. 2020;124:103936. doi: 10.1016/j. compbiomed.2020.103936

59. Rupasinghe HPV. Special Issue "Flavonoids and Their Disease Prevention and Treatment Potential": Recent Advances and Future Perspectives. Molecules. 2020;25(20):4746. doi: 10.3390/molecules 25204746

60. Russo M, Moccia S, Spagnuolo C, Tedesco I, Russo $\mathrm{GL}$. Roles of flavonoids against coronavirus infection. Chem Biol Interact. 2020;328:109211. doi: 10.1016/j. cbi.2020.109211

61. Liskova A, Samec M, Koklesova L, et al. Flavonoids against the SARS-CoV-2 induced inflammatory storm. Biomed Pharmacother. 2021;138:111430. doi: 10.1016/j.biopha.2021.111430

62. Bishayee A, Ahmed S, Brankov N, Perloff M. Triterpenoids as potential agents for the chemoprevention and therapy of breast cancer. Front Biosci. 2011;16(3):980-996. doi: 10.2741/3730

63. Xiao S, Tian Z, Wang Y, Si L, Zhang L, Zhou D. Recent progress in the antiviral activity and mechanism study of pentacyclic triterpenoids and their derivatives. Med Res Rev. 2018;38(3):951-976. doi: 10.1002/med.21484

64. Puttaswamy H, Gowtham HG, Ojha MD, et al. In silico studies evidenced the role of structurally diverse plant secondary metabolites in reducing SARSCoV-2 pathogenesis. Sci Rep. 2020;10(1):20584. doi: 10.1038/s41598-020-77602-0

65. Falade VA, Adelusi TI, Adedotun IO, Abdul-Hammed $\mathrm{M}$, Lawal TA, Agboluaje SA. In silico investigation of saponins and tannins as potential inhibitors of SARS-CoV-2 main protease (Mpro). Silico Pharmacol. 2021;9(1):9. doi: 10.1007/s40203-020-00071-w

66. Kurek J. Introductory Chapter: Alkaloids - Their Importance in Nature and for Human Life. In: Kurek J, ed. Alkaloids-Their Importance in Nature and Human Life. IntechOpen; 2019:1-6. doi: 10.5772/ intechopen. 85400

67. Gyebi GA, Adegunloye AP, Ibrahim IM, Ogunyemi OM, Afolabi SO, Ogunro OB. Prevention of SARS-CoV-2 cell entry: insight from in silico interaction of druglike alkaloids with spike glycoprotein, human ACE2, and TMPRSS2. J Biomol Struct Dyn. 2020:1-25. doi: 10.1080/07391102.2020.1835726

68. Varghese FS, van Woudenbergh E, Overheul GJ, et al. Berberine and Obatoclax Inhibit SARS-Cov-2 Replication in Primary Human Nasal Epithelial Cells In Vitro. Viruses. 2021;13(2):282. doi: 10.3390/ v13020282

69. Akkol EK, Genc Y, Karpuz B, Sobarzo-Sanchez E, Capasso R. Coumarins and Coumarin-Related Compounds in Pharmacotherapy of Cancer. Cancers (Basel). 2020;12(7):1958. doi: 10.3390/cancers12071959

70. Chidambaram SK, Ali D, Alarifi S, Radhakrishnan S, Akbar I. In silico molecular docking: Evaluation of coumarin based derivatives against SARS-CoV-2. J Infect Public Health. 2020;13(11):1671-1677. doi: 10.1016/j.jiph.2020.09.002

71. Maurya AK, Mishra N. In silico validation of coumarin derivatives as potential inhibitors against Main Protease, NSP10/NSP16-Methyltransferase, Phosphatase and Endoribonuclease of SARS CoV-2. J Biomol Struct Dyn. 2020:1-16. doi: 10.1080/07391102.2020.1808075

72. Das UN. Can Bioactive Lipids Inactivate Coronavirus (COVID-19)? Arch Med Res. 2020;51(3):282-286. doi: 10.1016/j.arcmed.2020.03.004

73. McCarty MF, DiNicolantonio JJ. Nutraceuticals have potential for boosting the type 1 interferon response to RNA viruses including influenza and coronavirus. Prog Cardiovasc Dis. 2020;63(3):383-385. doi: 10.1016/j. pcad.2020.02.007

74. Pendyalaa B, Patrasa A. In silico screening of food bioactive compounds to predict poten- tial inhibitors of COVID-19 main protease (Mpro) and RNA-dependent RNA polymerase (RdRp). ChemRxiv. 2020:11-44. doi: 10.26434/chemrxiv.12051927.v2

75. Huang S, Liu Y, Zhang Y, et al. Baicalein inhibits SARSCoV-2/VSV replication with interfering mitochondrial oxidative phosphorylation in a mPTP dependent manner. Signal Transduct Target Ther. 2020;5(1):266. doi: 10.1038/s41392-020-00353-x

76. Song J, Zhang L, Xu Y, et al. The comprehensive study on the therapeutic effects of baicalein for the treatment of COVID-19 in vivo and in vitro. Biochem Pharmacol. 2021;183:114302. doi: 10.1016/j.bcp.2020.114302

77. Liu $H$, Ye F, Sun $Q$, et al. Scutellaria baicalensis extract and baicalein inhibit replication of SARSCoV-2 and its 3C-like protease in vitro. J Enzyme Inhib Med Chem. 2021;36(1):497-503. doi: 10.1080/14756366.2021.1873977

78. Alrasheid AA, Babiker MY, Awad TA. Evaluation of certain medicinal plants compounds as new potential inhibitors of novel corona virus (COVID-19) using molecular docking analysis. Silico Pharmacol. 2021;9(1):10. doi: 10.1007/s40203-020-00073-8

79. Hisham Shady N, Youssif KA, Sayed AM, et al. Sterols and Triterpenes: Antiviral Potential Supported by InSilico Analysis. Plants. 2020;10(1):41. doi: 10.3390/ plants10010041

80. Wu Z, Chen X, Ni W, et al. The inhibition of Mpro, the primary protease of COVID-19, byPoria cocosand its active compounds: a network pharmacology and 
molecular docking study. RSCAdv. 2021;11(20):1182111843. doi: 10.1039/d0ra07035a

81. Ghosh R, Chakraborty A, Biswas A, Chowdhuri S. Identification of alkaloids from Justicia adhatoda as potent SARS CoV-2 main protease inhibitors: An in silico perspective. J Mol Struct. 2021;1229:129489. doi: 10.1016/j.molstruc.2020.129489

82. Zhang D-H, Wu K-L, Zhang X, Deng S-Q, Peng B. In silico screening of Chinese herbal medicines with the potential to directly inhibit 2019 novel coronavirus. J Integr Med. 2020;18(2):152-158. doi: 10.1016/j. joim.2020.02.005
83. Lung J, Lin $\mathrm{Y}-\mathrm{S}$, Yang $\mathrm{Y}-\mathrm{H}$, et al. The potential chemical structure of anti-SARS-CoV-2 RNA-dependent RNA polymerase. J Med Virol. 2020;92(6):693-697. doi: 10.1002/jmv.25761

84. Chandrashekharaiah PS, Kodgire S, Paul V, et al. Therapeutic Potential of Olive ' $s$ Bioactive Compounds in COVID-19 Disease Management. AIJR Prepr. 2020:127. https://preprints.aijr.org/index.php/ap/preprint/ view/269

85. Rutwick Surya U, Praveen N. A molecular docking study of SARS-CoV-2 main protease against phytochemicals of Boerhavia diffusa Linn. for novel COVID-19 drug discovery. Virusdisease. 2021;32:46-54. doi: 10.1007/ s13337-021-00683-6 